\title{
The Paradigm of Public Administration and its Development in Conditions of State Formation and Changes
}

\author{
Mykola O. Durman ${ }^{1}$, Alla H. Bashtannyk ${ }^{2}$, Viktoria Kornienko ${ }^{3,4}$, Azad E. \\ Omarov $^{5}$, Svitlana H. Levchenko ${ }^{6}$
}

\begin{abstract}
:
Purpose: The main purpose of this article is to study the processes of public administration and determine which concept of public administration should be taken as a basis. The development of the paradigm of public administration and its best practices is considered.

Design/Methodology/Approach: The study is based on a comprehensive approach to study the evolution of paradigms of public administration and the peculiarities of their application. It is noted that "directive public administration" (DPA), "new public management" (NPM), and "Good Governance" (GG) are progressive concepts for their time. This evolution is the development of public administration as a subsystem of the social system "state".

Findings: Being based on the analysis, the author proposed an improved model of transition from directive public administration through new public management to good governance (DPA - NPM - GG). This makes it possible to see the evolution of the public administration paradigm, as well as to identify the positive aspects of each of the concepts used in the public administration paradigm. This makes it possible to see the evolution of the public administration paradigm, as well as to identify the positive aspects of each of the concepts used in the public administration paradigm.

Practical Implications: As the main conclusion, it is noted that there is an opportunity for Ukraine to go quickly through the path of NPM and immediately begin to implement the concept of GG in public administration in modern conditions of state formation. It is espessialy important in the situation of the European and Euro-Atlantic integration of Ukraine.
\end{abstract}

Originality/Value: The research findings demonstrate that the use of advanced paradigms can significantly increase the efficiency of public administration and make it "human-

\footnotetext{
${ }^{1}$ Associate Professor, Kherson National Technical University, Kherson, 73008, Ukraine, E-mail: mykola.durman@gmail.com

${ }^{2}$ Deputy Director, Dnipro Regional Branch of the National School of Judges of Ukraine, Dnipro, 49600, Ukraine, E-mail: agba3118@gmail.com

${ }^{3}$ National Academy, headed by the President of Ukraine, Kyiv, 02000, Ukraine

${ }^{4}$ Associate Professor, Dnipropetrovsk Regional Instituite for Public Administration, Dnipro, 49000, Ukraine

${ }^{5}$ Associate Professor, Interregional Academy of Personnel Management, Kyiv, 03039, Ukraine, E-mail: 1970aaa@ukr.net

${ }^{6}$ Senior Researcher, Black Sea Research Institute of Economy and Innovation, Odesa, 65101, Ukraine, E-mail: lightstarpro@ukr.net
} 
oriented", as most of the provisions of the GG put the interaction of government and the public in the first place.

Keywords: Public administration paradigm, evolution of public administration paradigm, directive public administration, new public management, good governance.

JEL Codes: $C 1, C 4, C 58$.

Paper Type: Research paper.

\section{Introduction}

The study of public administration as a system, understanding the general laws of its structure and functioning as a system, prognostication its development as a system is very important at the present stage. It is interesting to study the development of paradigms of public administration with the identification of patterns of certain management processes. This would make it possible to optimize public administration and increase its efficiency. Considering public administration as a subsystem of the social system, it is better to point out that it influences most of all on the connections and processes that exist in the social system. Any system is forced to change the connections between the elements. This is due to the stages of its development and internal conditions and external disturbances. These functions are performed by the subsystem of public administration for the social system in the modern world (Holovatyi, 2015).

The New Public Manegement (NPM) is the result of a long period of searching for its effectiveness, which began when the largest nations faced a lack of resources on the threshold of global challenges. Their formation in the organizational model and practice of public administration took place in the second half of the 70's of the twentieth century (Flynn, 2002). Modernity is experienced by us as a stage of transformational transition, breaking the old order of management, its management structures and norms of control, as the formation of a new type of management. The global historical challenge forces modern theorists to reconsider many worldviews and methodological stereotypes in order to develop an adequate response project.

This article is a reflection on the current state of public administration and is based on scientific research of predecessors and personal experience. It is an attempt to analyze the evolution of public administration in a rapidly changing management environment. The tendencies, substantiation and scales of public administration reforms were discussed and recommendations on the evolution of the public administration paradigm and influences on its development were given.

\section{Literature Review}


Let's consider the following definition: "Management is an objective process of organizing systems, the essence of which is to ensure their integrity, maintain a given mode of operation and achieve the goal by exchanging information between their subsystems (controling and managed) through direct and reverse channels" (Dye, 2015). It gives us an understanding that two or more participants are involved in the management process. There are additional subsystems and the main goal is development. Public government is a kind of general government and that is why its purpose is the development of the country (its evolution).

However, any development and management works in conditions of limited resources (time, money, people, unideal processes, etc.). Manifestations of the limited evolutionism of the country were overcome by new approaches to the management of society and the state, among which theories of cyclical development (Therkildsen, 2017) and the theory of social change (Parsons, 1996) were distinguished.

The existence of different models and forms of government leads to ambiguous understanding and contradictions in the definition of components, both the social system (state) and the system of public administration. In general, the concept of system is a set of elements. There is a correlation and interaction between them and they form a single whole in common interaction. The social system is a complex and sophisticacily organized holistic formation, ordered and connected with a set of interdependent connections between its elements (Baraldi and Corsi, 2017).

Mueller (1989) according to the model of social choice, it is a competition of social or public policies proposed by politicians or political parties which are competing in the political process, ie schemes of further development of society and the nation as a whole and in certain aspects of public life. The winner in these competitions gets the right to implement his/her version of social development policy but in the role of the owner of state power. In this case it would seem quite reasonable to equate "public" or "social" and "governmental" policy.

However, in the situation of democracy, when the level of development of civil society is high enough, state power becomes virtually public administration and becomes significantly dependent on society due to the influence and constant control of civil society structures (Cleveland, 2002). In this case, it really makes sense to talk about "public power" as a combination of public administration and public selfgovernment. In this context, public policy is a broader concept, as it is carried out not so much by the state but by society as a whole (government agencies, businesses, NGOs, associations of citizens and separate individuals) to solve problems and meet the needs of society, its certain classes, groups, individuals (Mamun, 2018).

In his scientific work, Romanenko (2016) emphasizes the importance and role of communication in establishing an effective system of public administration and the 
use of interactive technologies and remote forms of communication to ensure internal communication.

Modern scholars emphasize the significant impact of the concepts of sustainable development and decentralization, community and territorial development on the system of public administration (Arabadzhyiev et al., 2020).

\section{Research Methodology}

The method of analysis used in the study is coming from the available literature. Selection methods were used in the subsequent selection of literature sources using appropriate criteria (such as keywords or possible paradigms). The method of study and generalization was used to collect data from scientific sources. All data related to public administration are relevant and appropriate to the objectives of our study and describe the functioning of public administration systems in different countries. Websites related to paradigms and concepts of public administration were also monitored.

The comparative method was taken as the main method of analysis. It was used to study the features of a particular concept of public administration and compare their advantages and disadvantages. The synthesis method was used to build an improved model of the relationship between the concepts of public administration. The forecasting method was used to develop recommendations to public authorities concerning the usage of appropriate concepts to build their own effective system of public administration.

\section{Empirical Findings}

The ability of the public administration system to evolutionary transformations is analyzed due to the systematical and functional aspect, which monitors the implementation of the existing management model and, if it is necessary, it can adjust it. Having used methods of structural, functional and comparative analysis of objects of management for this purpose, it is possible to say that the reasons of changes in systems of public management are changes of environment which dictate the conditions to the state.

Our society is now in the process of forming a New Public Management (NPM), but changing the needs of our society and the EU standards to which Ukraine aspires in its geopolitical development require the state to move to a new paradigm of public administration, such as "good governance" (GG). Noting such a property of social systems as self-government, we mean that humanity is characterized by the allocation of a separate function - the function of management. This is an attribute that distinguishes these systems from others. Based on the fact that this is only an attribute, management has always been seen as a sign, a property of the social system. 
However, based on the functional approach, ie considering management as a function of the social system, it is reasonable to identify the element or a group of elements of the system that manage it. So, the social systems necessarily form in their structure such a subsystem as management. Based on the system approach, it is the functions that determine the division of the system into elements and subsystems, as a set of elements that perform relatively separate functions in the system. So, let's assume, we will consider the management system as a subsystem for the social systems.

The term "management" often has a different meaning. For example, "administration" and "management" are very different management paradigms (Yang and Wang, 2017). It is impossible to unite them together, like political science and sociology. It is only possible to accept one of the paradigms and become its adherent.

The role of existing social structures and social institutions is qualitatively changing in modern society. In some cases they are not "the drive" but the brake of the development of society and the source of social crisis. Due to this, both management theorists and managers of different levels are trying to develop new management techniques. They want to create adequate and modern methods that can face changing social reality and ensure the effectiveness of management decisions. So, the science of management does not only conceptualize the past management experience. Economic theories and models used in a particular socio-economic formation of the country should also be studied in public administration. After all, it depends on the mechanisms and tools that can be used in public administration for the development of the state (Durman, 2019). It focuses on the future (desired, appropriate) condition of the managed organization, becomes a program for the implementation of the created model of the future society.

The classical (bureaucratic, directive) model of public administration (directive public administration, DPA), which dominated in the theory and practice of public administration, was severely criticized in the late 70's of the twentieth century (O'Toole, 1997). Basis for such criticism was the closed administrative and bureaucratic system, the low level of response to rapid changes in the environment, the slight influence of the public on the activities of public institutions. Efforts to "promote post-bureaucratic" forms have focused on opening up opportunities for public administration by them, beyound traditional control institutions and changing relations between social institutions.

The reorientation from bureaucratic administration and management to competitive markets and participation policy networks has been studied by researchers (Dunleavy and Hood, 1994), and transformations have been interpreted as an "inevitable change" to a more developed administration with convergence of administrative forms among developed countries. The model of new public management has played an important role in the development of public administration and in some developed democracies. The essence of the transition from the directive system of public 
administration to the paradigm of public management consists of such changes as (Haiming, 2017):

1. Orientation of state development on the solution of social problems, on the creating the conditions that ensure the best quality and a high level of human life as the highest value of society;

2. Formation of organizational and economic conditions for the implementation of the principles of economic freedom and economic independence by all economic entities of the state;

3. Transition from statistics to monitoring to carry out systematic analysis and control of the socio-economic, political and environmental situation in the country;

4. The assessment of the final result of state management depending on the degree of compliance of the level of economic development in the state and the level of living of the nation.

NPM has been the dominant paradigm in the theory and practice of public administration since the 1980s. NPM is described as a normative concept, very different from traditional public administration. It provides services that citizens really value. This concept increases the independence of public managers and reward organizations and individuals to increase production efficiency in the public sector. NPM is a paradigm of public administration that puts forward different relationships between governments, the civil service and the public, changes the traditional system of public administration. In most cases, an approach called "Management by Objectives (MBO)" is used (Projects for MBA, 2020). However, all approaches to the planning and implementation of public administration are kept (Figure 1).

Figure 1. The corelation of directive public administration (DPA) and new public management (NPM) (O'Flynn, 2007).

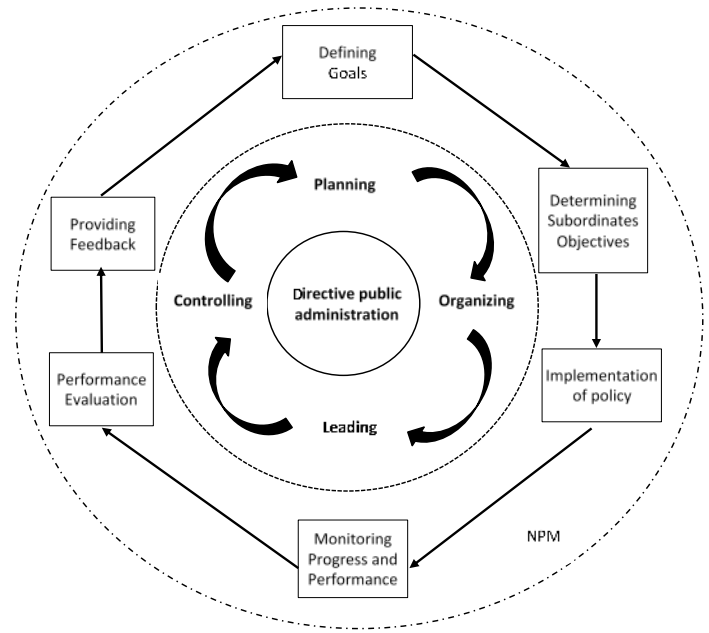

Source: Developed by the authors. 
In the center of the figure we can see the stages of centralized management directive public administration: planning, organization, implementation, control. The second tier shows the stages of the NPM. The stages of determining the effectiveness of the implementation of public administration and the stage of feedback are added. In this form, NPM has the ability to implement public administration more effectively, both in terms of achieving goals and satisfaction of the executor.

In recent decades, the NPM has become a hegemonic doctrine and public administration reforms have strongly incorporated its ideals and conditions. Both practitioners and scholars are increasingly interested in the idea of community value as a way of understanding government, informing about policy development and building service delivery. In some way, this is the answer to concerns about NPMs, but it also provides an interesting way of understandind what public sector organizations and public managers are actually doing. Therefore, it is necessary to study this new approach by revising the NPM and moving to newer paradigms of public administration. This provides a basis for a conceptual discussion of differences in approach, but also points to some practical implications for public administration.

But, in the late 80 's and early 90 's of the twentieth century in the Western political science and management science, the paradigm of NPM was replaced by the paradigm of GG. If NPM can be considered as a science and practice of managing socio-economic processes of the state in a market economy, then the public administration is seen by the GG as a process of political activity that requires its own mechanisms for developing and implementing comprehensive management decisions. Ukraine fall behind developed countries and only certain elements of the NPM apply in its public administration. However, this does not prevent us from trying to "skip" one stage and move immediately to the GG paradigm, bypassing the NPM paradigm.

At present, in the time of the global crisis, there is a question whether this paradigm of public administration is the one that best meets the challenges of new century governance. Taking this context into account, some authors conclude that it is necessary to combine the capabilities of NPM and GG in management reforms as a new management paradigm (Cago, 2017).

Most governments that have started a transformation of the ideology of the NPM have declared similar reform goals, which are as follows (Plumptre, 1999):

1. Reduction of government spending, maintaining a favorable climate for investment and competitiveness of domestic companies;

2. Increasing the manageability of society by the ruling elite;

3. Overcoming resistance to the implementation of legal policy and reducing a number of programs (social ones) by interested parties; 
4. Strict performance of the functions of the employer by the state and its transformation of the state into a responsible employer, attracting a sufficient number of employees with appropriate qualifications while limiting or reducing the total labor costs;

5. Improve the quality of services and strengthen public and private confidence in government.

If you go to a lower level - the level of the enterprise or small community, then you can define a balanced set of indicators that would reflect all aspects of the organization. In most cases, the basic units of measurement are as follows (Shashyna et al., 2018):

1. The cost and amount of funds spent on the acquisition of certain types of resources;

2. Costs and resources (eg human resources, materials, premises) that the organization uses to produce products or provide services;

3. Quantitative values of the volume of products or services provided that meet certain quality requirements;

4. Results and consequences, which are at least partly due to the fact that the organization produced products and sold them, provided certain services.

Activities in this direction should be based on the following principles (principles, criteria) by analogy with public administration in the EU. They have to fallow the requirements and principles of the modern management concept of GG. We propose to develop the previously considered paradigms and show their combination (Figure 2).

Figure 2. Improved scheme of public administration

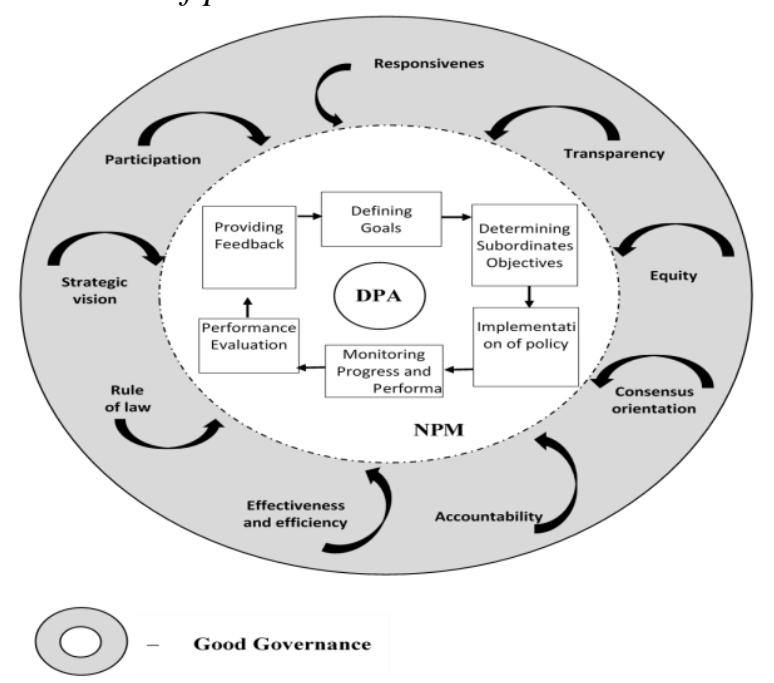

Source: Developed by the authors. 
At the same time, today we are on the threshold of radical changes in the system of public administration of Ukraine. Therefore, it is impossible to make ill-considered, simple decisions concerning both the modernization of public administration in general and the reform of the management system of the education sector in particular. That is why there is a desire to reveal better the concept of "good governance", including the management of the educational sector.

First of all, "Good Governance" means that governance is based on democratic principles of separation of powers, democracy and accountability of the executive, the rule of law, political pluralism, and freedom of media.

Secondly, the effectiveness of public administration is understood as the achievement of goals in a timely manner and with a reasonable minimum cost of public resources. At certain stages and under certain conditions, these two aspects of the governance process - efficiency and democracy - can be perceived as antipodes that contradict each other and are difficult to reconcile. Such opposition is especially typical for the initial stages of democratic transformations, when the scale and complexity of the tasks, the need to take unpopular economic and social measures greatly contribute to the spreading of the temptation of "authoritarian modernization."

But some scholars note the ineffectiveness of European practices in post-Soviet countries, linking it to the genetic inability of post-Soviet countries to adopt democratic values (Korzhenko and Khashieva, 2011). The global transformational processes of economic, political and social nature that took place in the late twentieth century necessitated the revision of numerous theories and concepts, shifting away from outdated models and the search for new alternative ways of developing society. In the background of these changes, Ukraine faces the challenge of forming a modern paradigm of public administration and building a management system on its basis that would meet the challenges of modern world and be able to function effectively in an information civilization (Akimova et al., 2020).

The main tasks of modern development of Ukraine are to determine the essence of public administration and the main directions of its reform. The modern period of development in our country requires a creating of new approaches to determining the role of the state in regulating socio-economic processes, finding effective mechanisms for implementing the functions of the state through efficient usage of basic resources (labor, financial and innovation) development.

The changes taking place in Ukrainian society require the modernization of the system of public administration and this will open opportunities for its development in modern conditions of social growth. The current model of public administration in Ukraine does not correspond to the country's strategic course aimed at European standards of democratic governance, as it is inefficient and prone to corruption, too centralized, closed to society and alienated from the needs of citizens. That is why 
the problem of improving the efficiency of public authorities and the quality of services provided by the state that meet modern requirements of society is relevant and socially significant (Bielova et al., 2017).

It is often heard that public administration in different countries has specific features due to cultural factors. In addition, public administration is heavily dependent on political and legal procedures. Therefore, when studying the legal procedures used in the implementation of public administration (administrative law), attention should be paid to compliance with all legal requirements for lawful and reasonable management decisions within the legislative and regulatory field (Marinetto, 2003). It is true, the differences are great. However, simple observation may indicate the similarity of models of public administration not only in the modern world, but throughout human history. Features, of course, take place. But behind them are common features. Public administration is evolving in one direction.

Public administration is changing and following the transformations that are taking place in society. Modern theories of public administration contain universal principles applicable to any state. There is a tendency to convergence (similarity with each other) of government systems and management models. The experience of the Anglo-Saxon countries is mainly a model for imitation (Dogaru, 2016).

However, in our opinion, the reasons for borrowing in public administration should be sought in the processes of globalization. At present, it is not an individual country that acts as a holistic system, but the world community as a whole. The processes taking place at the global level have an immediate impact on the development of many countries. This must be taken into account by the governments of states that are not only active in the international arena, but also by countries that face numerous domestic problems due to changes in international policy.

Within the framework of this methodology, it is possible to solve the problem of all its subsystems and the one that interests us - the system of public administration. Realizing the necessity of a qualitative change in the state of public administration, it is necessary to determine the vector of its movement. Ukraine has already chosen the geopolitical direction of the movement - integration into the EU and the organization of Euro-Atlantic cooperation.

\section{Discussion and Conclusions}

The social system is a complex and well-organized holistic formation, well-ordered and connected with a set of interdependent connections between its elements, which is characterized by self-development, self-regulation, self-management and selforganization. Highlighting the function of self-government, we conclude that social systems necessarily form its structure such a subsystem as management, which is divided into public and state management. 
The process of management in social systems begins with a change in the conditions of functioning or development of the object of management. Such a change leads to a change in the needs and motives of the object of management. This creates new management tasks.

There is a desire to apply proven management mechanisms of European countries to modern public administration, which will allow developing optimal mechanisms of public administration et all levels of government. One such mechanism is the concept of "good governance", which combines two basic elements: the democratic practice of making and implementing management decisions and efficiency. 'Good governance' is a strong state that is accountable to its citizens, based on the rule of law, and can provide its citizens with political stability. Effective public administration involves the conscious activities of political and public institutions, organizations aimed at regulating virtually all spheres of society, based on the principles of openness, participation of the general public in political decisionmaking, accountability and the rule of law. The evolution of public administration in Ukraine was extremely complex and heterogeneous, which was connected to the constant change of political life that had a significant influence on the development of public administration.Modern information technologies should be used in future to implement the GG concept and the 'GG-E-gov' symbiosis should be introduced.

\section{References:}

Akimova, L., Litvinova, I., Ilchenko, H., Pomaza-Ponomarenko, A., Yemets, O. 2020. The negative impact of corruption on the economic security of States. International Journal of Management, 11(5), 1058-1071.

Arabadzhyiev, D.Y., Buryk, Z.M., Barshatska, H.Y., Huba, M.I., Shashyna, M.V. 2020. Establishing interterritorial cooperation of amalgamated territorial communities as a tool to increase their capacity. International Journal of Management, 11(5), 10361044.

Baraldi, C., Corsi, G. 2017. Social systems theory. In: N. Luhmann (Ed.), Springer Briefs in Education. Springer, Cham, Switzerland, 11-36.

Bielova, O., Romanenko, Y., Kaydashev, R. 2017. Newly discovered circumstances in administrative legal proceedings of Ukraine. Journal of Advanced Research in Law and Economics, 8(2), 418-425. https://doi.org/10.14505/jarle.v8.2(24).10.

Cago, L. 2017. The 25 Best Governments In The World. Available at: https://www.worldatlas.com/articles/the-best-governments-in-the-world.html.

Cleveland, H. 2002. Nobody in Charge: Essays on the Future of Leadership. Jossey-Bass, San Francisco, CA.

Dogaru, T.C. 2016. The effect of public administration reforms under the post-new public management paradigm. University Library of Munich, MPRA Paper 94399, 743-753.

Dunleavy, P., Hood, C. 1994. From old public administration to new public management. Public Money \& Management, 4, 9-16.

Durman, M., Lopushinskyi, I. 2019. Correlation of mechanism of public administration and state regulation in developing state regulatory policy. In: O. Chukurna \& M. GawronŁapuszek (Eds.), Information and Innovation Technologies in Economics and 
Administration. Wydawnictwo Wyzszej Szkoly Technicznej w Katowicach, Katowice, Poland, 200-208.

Dye, T. 2015. Understanding Public Policy. Prentice Hall, Englewood Cliffs, NJ.

Fakhrul, I. 2015. New Public Management (NPM): A dominating paradigm in public sectors. Journal of Political Science and International Relations, 9(4), 141-151.

Flynn, N. 2002. Exlplaining the new public management: The importance of context. In: K. McLaughlin, S. Osborne \& E. Ferlie (Eds.), New Public Management: Current Trends and Future Prospects. Routledge, London, UK, 57-76.

Haiming, L. 2017. Research on public service outsourcing model from the perspective of governance paradigm shift: Taking social security as an example. Public Management Review, 1(19), 8.

Holovatyi, M. 2015. The state and society: The conceptual foundations and social interaction in the context of formation and functioning of states. Economic Annals-XXI, 9-10.

Korzhenko, V., Khashieva, L. 2011. Formation of the concept of Governance in the process of formation of modern European administrative space. Bulletin of the National Academy of Public Administration under the President of Ukraine, 2, 10-19. Available at: http://nbuv.gov.ua/UJRN/Vnadu_2011_2 4 .

Mamun, A. 2018. Functional transformation of district administration in Bangladesh: overview of the shift in development paradigm. European Journal of Political Science Studies, 2(1), 46-66.

Marinetto, M. 2003. Governing beyond the centre: A critique of the Anglo-governance school. Political Studies. 51(3), 592-608.

Mueller, D. 1989. Public choice. Edition 2. Cambridge University Press, Cambridge, MA.

O'Flynn, J. 2007. From new public management to public value: Paradigmatic change and managerial implications. The Australian Journal of Public Administration, 3(66), 353366.

O'Toole, L. 1997. The implications for democracy in a networked bureaucratic world. Journal of Public Administration Research and Theory, 7, 443-459.

Parsons, W. 1996. Public policy: An introduction to the theory and practice of policy analysis. Edward Elgar Publishing, Cheltenham, UK.

Plumptre, T. 1999. Governance and good governance: International and aboriginal perspectives. Institute On Governance. Available at: http://www.iog.ca/publications/govgoodgov.pdf.

Romanenko, Y. 2016. Place and role of communication in public policy. Actual problems of Economics. Scientific economic journal of the National Academy of Management, 2(176), 25-31.

Projects for MBA. 2020. Management by Objectives (MBO) - Definition, Need and its Limitations. Available at: https://www.projects4mba.com/management-byobjectives/1385/.

Shashyna, M., Zakharchenko, O., Darushyn, O., Buryk, M., Shpinkovska, M. 2018. Agroindustrial complex in the Eastern European countries in the context of sustainable development. The Journal of Social Sciences Research, Special Issue, 5, 549-562.

Therkildsen, O. 2017. Understanding public management through neopatrimonialism: a paradigm for all African seasons? In: U. Engel (Ed.), The African Exception. Routledge, New York, NY, 35-51.

Yang, L., Wang, Q. 2016. Analysis of network management technology and development trend in the future. Proceedings of the 2-nd International conference on computer science and electronics engineering. https://doi.org/10.2991/iccsee.2013.709. 